\title{
АНАЛИЗА НА МАЛЧИСКИТЕ И АКУШЕРСКИТЕ ФАКТОРИ ЗА РИЗИК ЗА ПРЕМАТУРНА РЕТИНОПАТИЈА КАЈ ПРЕМАТУРУСИЧИЈА ТЕЖИНА Е НАД 15ООГ И ГЕСТАЦИСКА ВОЗРАСТ НАД 30 НЕДЕЛИ
}

\author{
Игор Исјановски르, Виктор Исјановски²

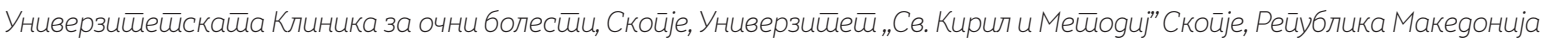

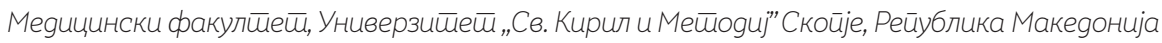

\section{Извадок}

Цитирање: Исјановски И, Исјановски В. Анализа на мајчинските и акушерските фактори за ризик за прематурна ретинопатија кај прематуруси чија за прематурна ретинопатија кај прематуруси чија недели. Арх Ј Здравје 2018: 10 (2); 64-70

Клучни зборови: фактори на ризик, ретинопатија, предвреме родени

*Кореспонденција: Игор Исјановски, Универзитетската клиника за очни болести, Универзитет „Св. Кирил и Методиј” Скопје, Република Македонија.E-mail: dr.isjanovski@gmail.com

Примено:17-мај-2018;Ревидирано:25-авг-2018; Прифатено: 30-авг-2018; Објавено: 30-сеп-2018 Печатарски права:` 2018 Игор Исјановски. Оваа статија е со отворен пристап дистрибуирана под условите на нелокализирана лиценца, која овозможува неограничена употреба, дистрибуција и репродvкција на било кој медиум, доколку се цитираат оригиналниот(ите) автор(и) и изворот

Конкурентски интереси: Авторот изјавува дека нема конкурентски интереси.

Прематурната ретинопатија (РОП) е главна причина за слепило кај предвремено родените бебиња. Инциденцата на РОП се зголемува во земјите во развој и се должи на зголемување на преживување на предвремено родените деца. Прематурната ретинопатија (РОП) е сериозна компликација кај предвремено родени деца која може да доведе до слепило, освен ако се дијагностицира и се третира рано. Цел на оваа студија е да се проучат мајчините и акушерските фактори на ризик за РОП. Материјал и методи: Истражувањето преставува аналитичка "Case control" студија во периодот 2015-2016г. Во студијата се вклучени 163 предвреме родени деца кои не ги исполнуваат критериумите на Американската академија за офталмологија (ААО), со родилна тежина се над 1500 г и гестациска старост над 30 недела. Мајките се поделени во две групи во однос на новородените со РОП и без. За оставрување на целите се користеше дводелен анкетен прашалник, првиот дел од прашалникот се однесува на прашања за мајката. Резултати: ИВФ (ин витро фертилизациа) ја зголемува веројатноста за РОП повеќе од два пати OR=2.1256 (1.1133-4.0585). Како независни фактори мултипната бременост ја зголемува веројатноста за РОП за два и пол пати. Прееклампсијата делува протективно, ја намалува веројатноста за настанување на РОП. Начинот на породување, возраста на мајката, број на бремености, број на раѓања, консумирање на алкохол, пушење, наркотици не претставуваат ризик фактори. Треба да се обрне големо внимание на дефинирањето на ризик факторите, нивната комплексност, развојот и прогресијата на прематурната ретинопатија и нејзината превенција кои се само еден дел од прашањата со кој се соочуваат офталмолозите и неонатолозите во текот на својата работа. Во студијата се потврдија истите ризик факори кои се регистрираат на кај прематурусите според ААО (родилна тежина под 1500 г и под 30-та гестациска недела). Заклучок: протоколите за скрининг на РОП да се модифицираат, покрај инклузионите критериуми на АAO да се вклучат и прематуруси според препораката на неонатолозите за зголемен ризик за развој на прематурна ретинопатија, а се со родилна тежина над 1500 г и над 30-та гестациска недела.

\section{CLINICAL SCIENCE}

\section{ANALYSIS OF MATERNAL AND OBSTETRIC RISK FACTORS FOR PREMATURE RETINOPATHY IN PREMATURES WHOSE WEIGHT WAS OVER 1500G AND GESTATIONAL AGE ABOVE 30 WEEK}

\author{
Igor Isjanovski1 ${ }^{1}$ Viktor Isjanovski²
}

\author{
University Clinic for Eye Diseases, Medical faculty, Ss. Cyril and Methodius University Skopje, Republic of Macedonia \\ Medical faculty, Ss. Cyril and Methodius University Skopje, Republic of Macedonia
}

Citation: Isjanovski I, Isjanovski V. Analysis of maternal and obstetric risk factors for premature

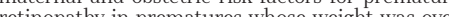
1500g and gestational age above 30 week. Arch Pub Health 2018: 10 (2); $64-70$ (English)

Key words: risk factors, retinopathy, premature neonates

*Correspondence: Igor Isjanovski, University Clinic for Eye Diseases, Medical faculty, Ss. Cyril and Methodius University Skopje, Republic of Macedonia. E-mail: dr.isjanovski@gmail.com

Received: 17-May-2018; Revised: 20-Jul-2018; Accepted: 18-Aug-2018; Published: 30-Sep-2018 Copyright:@ 2018. Igor Isjanovski. This is an open-access article distributed under the terms of the Creative Commons Attribution License, which permits unrestricted use, distribution, and reproduction in any medium, provided the original author(s) and source are credited.

Competing Interests: The author have declared that no competing interests

\section{Abstract}

Retinopathy of Prematurity (ROP) is a major cause of preventable blindness in preterm infants. The incidence of ROP is increasing in developing countries due to increased survival of preterm infants. Retinopathy of prematurity (ROP) is a serious complication of prematurity and can lead to blindness unless is recognized and treated early. The aim of our study was to study maternal and obstetric risk factors for ROP. Material and methods: The research was an analytical „Case control" study in the period 2015-2016. The study included 163 premature babies that not meet the criteria of the American Academy of Ophthalmology (AAO), with BW more than $1500 \mathrm{~g}$ and gestational age more than $30 \mathrm{GW}$. Mothers were divided into two groups according the newborns with ROP and without. In order to achieve the goals, a two-part survev questionnaire was used, the first part of the questionnaire refers to questions for the mother. Results: In Vitro Fertilization increases the chance of ROP two times $\mathrm{OR}=2.1256$ (1.1133-4.0585). As independent factors, multiple pregnancies increase the chance of ROP for fourth times OR $=4.0721$ (2.3899-9.2511). Preeclampsia acts protective, reduces the chance of occurrence of ROP OR $=0.2147$ (0.0706-0.6526). The way of delivery, the number of pregnancies, number of births, alcohol consumption, smoking, narcotics, did not present as risk factors. Conclusions: We should pay attention to the definition of risk factors, their complexity, the development and progression of retinopathy prematurnata and its prevention, because thev are just one of the issues facing ophthalmologists and neonatologists throughout his work. The study confirmed the same risk factors that are registered on neonatal premathuruses according to AAO (birth weight below $1500 \mathrm{~g}$ and under the 30th gestation week). Conclusion: Based on the analysis of the study, a conclusion and recommendation protocols criteria to screen for ROP to modify, despite inclusion criteria of AAO to include premature neonates in screening for ROP according to the recommendation of neonatologists to increased risk of premature retinopathy, with birth weight over $1500 \mathrm{~g}$ and over 30 gestation weeks. 


\section{Introduction}

Premature retinopathy or Retinopathy of prematurity-ROP is a disease that occurs in premature babies and involves the blood vessels of the retina of the eye during development. This results in the development of vascular shunts, with neovascularization and in more severe forms, with traction ablation of retina. The development of retinal vascular shunts and neovascularization in ROP are believed to be related to local ischemia, which is a dominant feature of other proliferative retinopathies such as sickle-cell retinopathy and diabetic retinopathy. The only specificity of ROP refers to its occurrence only in premature infants with an immature and incomplete vascularized retina ${ }^{1-4}$.

In premature babies, normal development of retinal blood vessels can be interrupted, so that the peripherally placed parts during their development remain without vascularization. Ischemia that stimulates neovascular proliferation occurs in peripheral parts of the retina. The development of vitreoretinal proliferation and traction ablation of the retina on this surface causes permanent loss of eye function ${ }^{1-3,5}$.

There are numerous risk factors responsible for the development of premature retinopathy that obstruct the normal development of retinal vascularity, among which maternal and obstetric risk factors and many others that combine and complement each other.

This eye condition tends to occur only in premature babies. It usually affects both eyes and is the leading cause of vision loss in children. Out of the 28,000 U.S. babies born weighting less than $1500 \mathrm{~g}$ as many as 16,000 will develop some form of ROP. Fortunately, most of these 90\% have a mild case and won't need treatment. More severe forms of ROP can cause vision loss and even blindness if not treated ${ }^{1-3,6}$.

Other risk factors that could contribute to the ROP over the years, surprisingly, research has lead to findings that pre-eclampsi in the mother can lead to a more favorable outcome for newborns, the researchers explain it that stress causes hypertension and intrauterine late maturation of eye $\mathrm{e}^{1-3,8-10}$. The research of in vitro fertilization as a risk factor is contradictory. Friling et al found no significant differences in the incidence and severity of ROP between IVF and natural conception, such as Chinese and Korean studies 12,13. Watts P. and Adams GGW register that IVF- children with ROP had lower gestational age and birth weight than those IVF babies who have not developed ROP. IVF according to them is a risk factor for the development of ROP. They in their research register that $41.6 \%$ of IVF babies progress to stage 3 ROP compared with only $9.3 \%$ of naturally conceived children ${ }^{14}$. Conceiving with IVF, unlike other techniques is a major risk factor for the development of ROP. The authors advise to increased vigilance in screening babies conceived by IVF method. ${ }^{1-3,15-16}$. McKibbin and Dabbs after treatment with IVF, $20 \%$ of babies were fulfilling screening criteria for ROP ${ }^{17}$.

Mother's smoking has been identified as an important risk factor for ROP18 In 2006, suggest that elevated mother's glucose can also play a role in the risk factor ${ }^{19-21}$

The aim of the study was to identify and analyse maternal and obstetric risk factors for retinopathy of prematurity in prematures whose weight was over $1500 \mathrm{~g}$ and gestational week above 30 .

\section{Materials and methods}

The research was an analytical „case control" study (retrospective with prospective approach) in the period 20152016. The study included 163 premature babies that did not fulfills criteria according the American Academy of Ophthalmology (AAA) (birth weight $<=1500$ $\mathrm{g}$ and gestational age $<=30$ weeks). They were examined outside the AAO protocol, and in cooperation with neonatologists. They are involved because of a recommendation of neonatologists because of the possibility to develop ROP. They were prematuruses whose birth weight were above $1500 \mathrm{gr}$ and gestational age over 30 weeks In order to achieve the objectives used two-part questionnaire designed specifically suited for this pur- 
pose and clinical examination.

The group was divided into premature with ROP and without ROP.

The first part of the questionnaire refers to questions about the mother, and the second part is filled in by the doctor. First part: Method of fertilization / natural pathway and in vitro fertilization, type of pregnancy (one child, twins, triplets), number of pregnancies and births, multiple prenatal maternal factors - smoking, alcohol, drugs, diabetes, preeclampsia, the age of the mother, the method of deliver.

Inclusion criteria of prematuruses in screening for early detection of ROP: birth weight (BW) which was over 1500 gr. and Gestational age (GW) which was over 30 .Exclusive criteria: Infants with ocular congenital anomalies, such as cataracts, microphthalmia, anophthalmia, and coloboma in one or both eyes or systemic anomalies.

The Data were analyzed with Statistical Package for the Social Sciences (SPSS for windows, version 17.0). Descriptive statistics include mean and standard deviation for numerical variables, and percentage of different categories of categorical variables. Comparison of groups was done by chi-square $\left(\mathrm{X}^{2}\right)$ test and t-test. Odd ratio was constructed of the risk factors that were significant. For CI (confidence interval $\pm 95 \% \mathrm{CI}$ ) is defined statistical significance level of error of less than 0,05 (p) The results are presented in tables and graphics.

\section{Results}

The study included 163 premature babies, of which $63(38.7 \%)$ were with ROP and 100(61.3\%) were without ROP.

In the group of preterm infants, IVF was registered in 63 mothers, and natural reproduction in 100 mothers. In the group of mothers with IVF, in preterm infants, ROP was found in $47.1 \%$, \%, and in $52.9 \%$ not. In the group of mothers with natural fertility, in preterm infants ROP was registered at $29.5 \%$, and not at $70.7 \%$.The percentage difference between preterm infants with ROP of was statistically significant for $\mathrm{p}<0.05$ ( $\mathrm{p}=0.0212$, Difference test). A statistically significant association between the fertilization method and the registration of ROP for $p<0.05$ (Pearson Chi-square: 5.2965, $\mathrm{p}=.021368$ ) was recorded. According Odds ratio IVF increases the chance for ROP was two $\mathrm{OR}=2.1256(1.1133-4.0585)$.

According the delivery, in the group of mothers with caesarea section, in preterm infants, ROP was found in $40.6 \%$, and in $59.4 \%$ not. In the group of mothers with vaginal delivery, in preterm infants ROP were registered at $35.4 \%$, and not at $64.6 \%$. There was no statistically significant association between the way of delivery and registration of ROP for p> 0.05 (Pearson Chi-square: 0.4231, p = $0.515398)$.

Multiple pregnancies in a greater percentage of $63.5 \%$ were registered in the ROP group, and in the group without ROP it was registered with $27.0 \%$, the percentage difference was statistically significant for $\mathrm{p}<0.05(\mathrm{p}=0.000)$. There was statistically significant association between the multiple pregnancies and registration of ROP for $\mathrm{p}<0.05$ (Pearson Chisquare: $21.2608, p=0.00008)$. According to the Odds-ratio, multiple pregnancies increase the chance for ROP four times $\mathrm{OR}=4.0721$ (2.3899-9.2511)

In both groups a statistically significant greater percentage mothers did not smoke (90.5\%, 90.0\%). There was no statistically significant association between the smoking and registration of ROP for $\mathrm{p}>0.05$ (Pearson Chi-square: 0.0099, $\mathrm{p}=$ 0. 920740).

In the group with ROP, mothers do not consume alcohol $96.9 \%$ and consume $3.1 \%$. In the group without ROP, mothers do not consume alcohol 98.4\%, and consume $1.6 \%$ There was no statistically significant association between alcohol consumption and the manifestation of ROP for $\mathrm{p}>0.05$ (Pearson Chi-square: $.07567, \mathrm{p}=.384372)$.

In the group with ROP, mothers did not take narcotic substances $84.1 \%$ and took $15.9 \%$. In the group without ROP mothers did not take narcotic substances $88.0 \%$ and took $12.0 \%$. There was no statistically significant association between maternal use of narcotic substances and 
the manifestation of ROP for $\mathrm{p}>0.05$ (Pearson Chi-square: 0.4966, $\mathrm{p}=.481008$ ).

In the group with ROP, pre-eclampsia was not manifested in $93.6 \%$ and was manifested at $6.4 \%$. In the group without ROP, pre-eclampsia was not manifested in $76.0 \%$ and was manifested at $24 \%$. There was statistically significant association between the pre-eclampsia and registration of ROP for $\mathrm{p}<0.05$ (Pearson Chi-square: 8.4638, $\mathrm{p}=0.003622)$. According to the Odds-ratio, pre-eclampsia was not a risk factor, it acts protective (reduces the chance) for ROP, OR $=0.2147$ (0.0706-0.6526)

One mother with diabetes was registered in the group with ROP (table 1).

Table No 1

\begin{tabular}{|c|c|c|}
\hline & $\mathrm{N}=163$ & $\%$ \\
\hline with ROP & 63 & 38.7 \\
\hline without ROP & 100 & 61.3 \\
\hline way of fertilization & $\operatorname{IVF}(\mathrm{N} / \%)$ & natural fertilization(N/\%) \\
\hline with ROP & $40 / 47.1$ & $23 / 29.5$ \\
\hline without ROP & $45 / 52.9$ & $55 / 70.5$ \\
\hline way of delivery & Caesarean section(N/\%) & Vaginal delivery (N/\%) \\
\hline with ROP & $41 / 40.6$ & $22 / 35.5$ \\
\hline without ROP & $60 / 59.4$ & $60 / 64.5$ \\
\hline pregnancy $\quad$ single(N/\%) & $\operatorname{twin}(N / \%)$ & triplets(N/\%) \\
\hline with ROP $\quad 23 / 37.5$ & $37 / 58.7$ & $3 / 4.8$ \\
\hline $\begin{array}{ll}\text { without ROP } & 73 / 73.0\end{array}$ & $29 / 29.0$ & $1 / 1.0$ \\
\hline smoking & yes $N / \%$ & no $N / \%$ \\
\hline with ROP & $6 / 9.5$ & $57 / 90.5$ \\
\hline without ROP & $10 / 10.0$ & $90 / 90.0$ \\
\hline alcohol & yes $N / \%$ & no $N / \%$ \\
\hline with ROP & $1 / 1.6$ & $62 / 98.4$ \\
\hline without ROP & $4 / 4.0$ & $96 / 96.0$ \\
\hline narcotic substances & yes $N / \%$ & no $N / \%$ \\
\hline with ROP & $10 / 15.9$ & $53 / 84.1$ \\
\hline without ROP & $12 / 12.0$ & $88 / 88.0$ \\
\hline pre-eclampsia & yes $N / \%$ & no $N / \%$ \\
\hline with ROP & $4 / 6.3$ & $59 / 92.1$ \\
\hline without ROP & $24 / 24.0$ & $76 / 76.0$ \\
\hline diabetes mellitus & yes $N / \%$ & no $N / \%$ \\
\hline with ROP & $1 / 1.6$ & $62 / 98.4$ \\
\hline without ROP & & $100 / 100.0$ \\
\hline
\end{tabular}

\section{Discussion}

Retinopathy is the most important cause of blindness in children, which in many cases can be prevented. Although great progress has been made in the diagnosis and treatment of ROP, it is one of the major diseases causing blindness in children ROP is a multifactorial disease, involves many risk factors. The definition of risk factors, their complexity, the development and progression of premature retinopathy and its prevention are just some of the issues facing ophthalmologists and neonatologists ${ }^{22}$. 
Assessment of IVF in the occurrence of premature retinopathy is debatable, i.e. different authors have come up with different conclusions. Berg et al ${ }^{23}$ have come to the conclusion that IVF is closely related to the emergence of ROP in premature babies. In contrast, Friling et al. ${ }^{24}$ did not find significant differences in the occurrence and severity of premature retinopathy between the natural conception and IVF. Watts and Adams ${ }^{25}$ come to the conclusion in their study that IFV more often than other artificial insemination techniques were a major risk factor for developing a severe form of ROP. In our study we came to the conclusion that IVF increases the chance for ROP more than two and a half times.

ROP occurs in a greater percentage in multiple pregnancies in relation to single pregnancy in mothers, multiple pregnancy increases the chance of ROP for tri times. Blumenfeld et al. ${ }^{26}$ in a large series reported that there was no difference in the incidence or severity of ROP between single or multiple pregnancies. The antenatal risk factors analysis in Kumar's study showed that multiple pregnancies were significant in the ROP group $(\mathrm{p}=$ $0.00)^{27}$.

In the study of Seiberth and Lindarkomp, ${ }^{28}$ were registered insignificant relationship between the mode of delivery and the occurrence of ROP. But it is in disagreement with Shah et al. ${ }^{29}$ who found that cesarean section was significantly associated with the occurrence of ROP. No significant relationship has been gained between the mode of delivery (caesarean section and spontaneously) and the occurrence of ROP in our study.

The study did not obtain a link between the number of births and the registration of premature retinopathy.

Babic GS ${ }^{30}$, concluded in her study that smoking before pregnancy, during pregnancy, how many cigarettes are smoked per day, the level of mother's education and the socioeconomic factors were risk factors for the occurrence of ROP.

However, smoking of the mother was not recommended due to the large number of systemic side effects that can cause the mother and the newborn. In our study neither confirmed nor denied smoking that was a risk factor for the occurrence of ROP and was not denied and did not confirm that it acts protective for the occurrence of premature retinopathy. We obtained these results on the basis of the small number of mothers who smoke in the group.

There was no statistically significant link between alcohol consumption and ROP manifestation in the group. There was also no significant link between the consumption of narcotic substances and the manifestation of ROP in both groups. In contrast to our obtained results, Babić $3^{0}$ came to the opposite conclusion that the consumption of alcohol and narcotic substances is a risk factor for the occurrence of ROP.

However, very few studies have been published on the relationship between preeclampsia and ROP, and they are contradictory 22, 30-33. Filho et al. in their study concluded that preeclampsia reduces the risk of ROP by $60 \%$ and is a protective factor ${ }^{31}$. Seibrth came to the same conclusions in his research ${ }^{28}$. The findings of Filho and Seibrth were similar to ours. In our study, preeclampsia was not a risk factor, but rather acts as a protective factor, reduced the chance of ROP occurring. Studies in Turkey have found that preeclampsia was a risk factor precisely, and Gebesce et al. ${ }^{34}$ study find that the odds ratio $=$ OR for maternal preeclampsia with the univariate logistic regression was OR=3.2 (1.002-11.535), and was confirmed by the Özkan study and colleagues $^{35}$.

Tunay et al. in their research found that diabetes in the mother was a risk factor for the occurrence of ROP 36 the mother's diabetes was registered as an independent risk factor for $\mathrm{ROP}-\mathrm{OR}=25,040$ $(12,728-49,264,311)$. In our research, 4 cases of mothers of diabetics were registered.

\section{Conclusions}

- In vitro fertilization, multiple pregnancies were risk factors and increase the chance of premature retinopathy occurring. 
- Preeclampsia was not a risk factor for ROP, but it has a protective effect

- In the study the next factors were not risk factors for the occurrence of premature retinopathy: the method of delivery (caesarean section and spontaneous), number of pregnancies, number of births, alcohol, smoking and narcotics.

The study confirmed the same risk factors that are registered on neonatal prematurus according to AAO (birth weight below $1500 \mathrm{~g}$ and under the 30th gestation week). Based on the analysis of the study, a conclusion and recommendation are that protocols criteria to screening for ROP have to modify, despite inclusion criteria of AAO to include prematurus in screening for ROP according to the recommendation of neonatologists which increased risk of premature retinopathy, with birth weight over $1500 \mathrm{~g}$ and over 30 gestation weeks

\section{References}

1. Isjanovski I.\& Golubovic M. Retinopathy of prematurity: some risk factors. Physioacta 2016; 10 (3): 63-70.

2. Isjanovski I, Sazdovska S, Jordanova Dimovska V. Incidence and risk factors for retinopathy of prematurity. Physioacta 2017; 11(1):49-56.

3. Исјановски И. Проценка на влијанието на Ин витро фертилизацијата во настанувањето на прематурната ретинопатија ( РОП ). Докторска дисертација, 2017. Медицински факултет Скопје, Универзитет Св. Кирли и Методиј.

4. Wheatley C M, Dickinson J L, Mackey D A, Craig J E, Sale M M. Retinopathy of prematurity: recent advances in our understanding. Br J Ophthalmol 2002; 86(6): 696-700.

5. Tasman W. Retinopathy of Prematurity: the life of a lifetime disease. Am J Ophthalmol 2006; 141(1): 167-74.

6. Oros A, Otkrivanje, lecenje i prevencija razvoja Prematurne Retinopatije.Doktorska disertacija, Novi Sad, 2002
7. Татеши Б. Прематурна ретинопатија-скрининг и современа терапија, докторска дисертација, Скопје, 2016. Медицински факултет Скопје, Универзитет Св. Кирли и Методиј.

8. Das A. \& McGuire PG. Retinal and Choroidal angiogenesis: pathophysiology and strategies for inhibition. Progress in Retinal and Eye Research 2003; 22(6):721-48.

9. Gibson DL et al. Retinopathy of prematurity-induced blindness: birth weight-specific survival and the new epidemic. Pediatrics 1990; 86(3): 40512.

10. Phelps DL. Retinopathy of prematurity: an estimate of vision loss in the United States1979. Pediatrics 1981; 67(6): 924-5.

11. Akeson N. \& B. Bonapart. What is the current incidence of RLF. Pediatrics 1976; 58(4): 627.

12. Silverman WA. Retrolental fibroplasia: a modern parable. Grune \& Stratton1980. Retrieved 21 September 2013

13. Silverman, William A. The Consequences of Oxygen Restriction. In: Retrolental fibroplasia: a modern parable. 1980. Grune \& Stratton. Retrieved 21 September 2013.

14. Watts P, Adams GG. In vitro fertilisation and stage 3 retinopathy of prematurity. Eye (Lond) 2000; 14:330333.

15. Cross KW. Cost of preventing retrolental fibroplasias. Lancet 1973; 2:954-956.

16. Gilbert C, Rahi J, Eckstein M, O'Sullivan J, Foster A. Retinopathy of prematurity in middle-income countries. Lancet 1997; 350:954-956

17. Gilbert C. Retinopathy of prematurity: A global perspective of the epidemics, population of babies at risk and implications for control. Early Human Develpoment 2008; 84:77-82.

18. Hirabayashi H, Honda S, Morioka I, Yokovama N, Sugivama D, Nishimura K, Matsuo M, Negi A. Inhibitory 
effects of maternal smoking on the development of severe retinopathy of prematurity. Eye 2010; 24: 10241027

19. Blanco CL, Baillargeon JG, Morrison RL, Gong AK. Hyperglycemia in extremely low birth weight infants in a predominantly hispanic population and related morbidities. J Perinatol 2006; 26:737-741.

20. Ertl T, Gyarmati J, Gaal V, Szabo I. Relationship between hyperglycemia and retinopathy of prematurity in very low birth weight infants. Biol Neonate 2006; 89:56-59.

21. Garg R, Agthe AG, Donohue PK, Lehmann CU.Hyperglycemia and retinopathy of prematurity in very low birth weight infants. J Perinatol 2003; 23:186-194.

22. Bergh T, Ericson A, Hillensjo T, Nygren KG, Wennerholm UB. Deliveries and children born after in-vitro fertilisation in Sweden 1982-95: a retrospective cohort study. Lancet 1999; 354: 1579-1585.

23. Friling R, Axer-Siegel R, Hersocovici Z, Weinberger D, Sirota L, Snir M. Retinopathy of prematurity in assisted versus natural conception and singleton versus multiple births. Ophthalmology 2007; 114(2):321-324.

24. Watts P, \& Adams GGW. In vitro fertilisation and stage 3 retinopathy of prematurity. Eye 2000; 14: 330-333.

25. Blumenfeld LC, Siatowski RM, Feuer WJ, et al. Retinopathy of prematurity in multiple-gestation pregnancies. Am J Ophthalmol 1998;125:197-203.

26. Kumar MA., Rajalakshmi AR, Gunasekaran D, Sreeraaganidhi. A study of risk factors for retinopathy of prematurity in a medical college hospital in South India to evaluate the criteria for screening for retinopathy of prematurity. Journal of current trends in clinical medicine \& laboratory biochemistry 2014; 2(2): 31-36.

27. Seiberth V \& Linderkamp O. Risk factors in retinopathy of prematurity. A multivariate statistical analysis.
Ophthalmologica 2000; 214(2):131135.

28. Shah VA, Yeo CL, Ling YL. Incidence, risk factors of retinopathy of prematurity among very low birth weight infants in Singapore. Ann Acad Med Singapore 2005; 34:169-78.

29. Stanković BG, Oros A, Vujanović M, Cekić S, Jonović M. Some of the risk factors for retinopathy of prematurity. Acta Medica Medianae 2014; 53(3): 5-10.

30. Zayed MA, Uppal A, Hartnett ME. New-onset maternal gestational hypertension and risk of retinopathy of prematurity. Invest Ophthalmol Vis Sci 2010; 51(10): 4983-4988.

31. Fortes Filho JB, Costa MC, Eckert GU, Santos PG, Silveira RC, Procianoy RS. Maternal preeclampsia protects preterm infants against severe retinopathy of prematurity. J Pediatr 2011; 158(3): 372-376.

32. Dhaliwal CA, Fleck BW, Wright E, Graham C, McIntosh N. Retinopathy of prematurity in small-for-gestational age infants compared with those of appropriate size for gestational age. Arch Dis Child Fetal Neonatal Ed 2009; 94(3): F193-F195

33. Palmer EA, Flynn JT, Hardy RJ, et al. The cryotherapy for retinopathy of prematurity cooperative group. Incidence and early course of retinopathy of prematurity. Ophthalmology 1991; 98(11):1628-1640.

34. Gebesce Arzu et al. Retinopathy of prematurity: incidence, risk factors, and evaluation of screening criteria, Turk J Med Sci 2016; 46: 315-320.

35. Özkan H, Cetinkaya M, Koksal N, Özmen A, Yıldız M. Maternal preeclampsia is associated with an increased risk of retinopathy of prematurity. J Perinat Med 2011; 39: 523-527.

36. Tunay ZÖ, Özdemir Ö, Acar DE, Öztuna D3, Ura区 N. Maternal diabetes as an independent risk factor for retinopathy of prematurity in infants with birth weight of $1500 \mathrm{~g}$ or more. Am J Ophthalmol 2016;168:201-206. 